
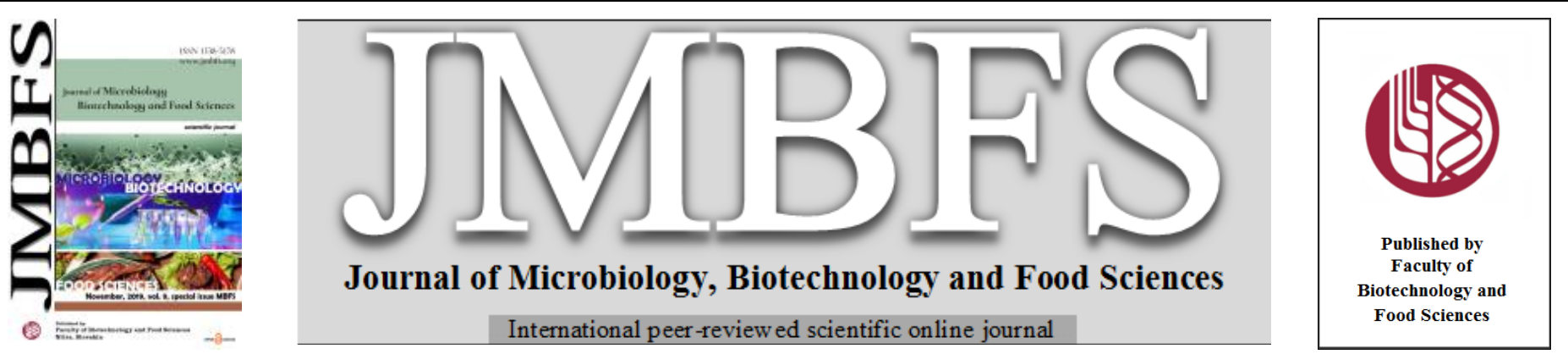

\title{
MICROBIOTA OF THE TRADITIONAL SLOVAK SHEEP CHEESE "BRYNDZA"
}

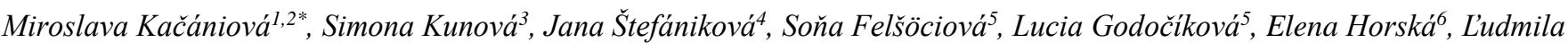 Nagyová, Peter Hašč́l $k^{7}$, Margarita Terentjeva ${ }^{8}$}

\section{Address(es):}

${ }^{1}$ Slovak University of Agriculture in Nitra, Faculty of Horticulture and Landscape Engineering, Department of Fruit Sciences, Viticulture and Enology, Trieda Andreja Hlinku 2, 94976 Nitra, Slovakia, phone number: +421 376414715.

${ }^{2}$ University of Rzeszow, Faculty of Biology and Agriculture, Department of Bioenergy and Food Technology, Zelwerowicza St. 4, PL-35601 Rzeszow, Poland.

${ }^{3}$ Slovak University of Agriculture, Faculty of Biotechnology and Food Sciences, Department of Food Safety and Hygiene, Trieda Andreja Hlinku 2, 94976 Nitra, Slovakia, phone number: +421 376415807 .

${ }^{4}$ Slovak University of Agriculture in Nitra, AgroBioTech - Research Center, Tr. A. Hlinku 2, 94976 Nitra, Slovakia.

${ }^{5}$ Slovak University of Agriculture in Nitra, Faculty of Biotechnology and Food Sciences, Department of Microbiology, Trieda Andreja Hlinku 2, 94976 Nitra, Slovakia, phone number: +421376415812.

${ }^{6}$ Slovak University of Agriculture, Faculty of Economics and Management, Department of Marketing and Trade, Trieda Andreja Hlinku 2, 94976 Nitra, Slovakia, phone number: +421 376414102 .

${ }^{7}$ Slovak University of Agriculture in Nitra, Faculty of Biotechnology and Food Sciences, Department of Technology and Quality of Animal Products, Trieda Andreja Hlinku 2, 94976 Nitra, Slovakia, phone number: +421 376414708.

${ }^{8}$ Latvia University of Life Sciences and Technologies, Institute of Food and Environmental Hygiene, Faculty of Veterinary Medicine, Latvia K. Helmaña iela 8, LV3004, Jelgava, Latvia.

*Corresponding author: miroslava.kacaniova@gmail.com

doi: 10.15414/jmbfs.2019.9.special.482-486

\section{ARTICLE INFO}

Received 30. 6. 2019

Revised 17. 10. 2019

Accepted 22. 10. 2019

Published 8. 11. 2019

Regular article OPEN $\partial_{\text {ACCESS }}$

\begin{abstract}
The aim of the present study was to describe microbiota of the traditional Slovak cheese „Bryndza“. A total of 30 cheese samples were collected from seven different farms during in 2019. The microbiota studies included the total bacterial count, coliforms, enterococci, lactic acid bacteria, and yeasts. The total bacterial counts were cultivated on plate count agar at $30^{\circ} \mathrm{C}$ in aerobic conditions, lactic acid bacteria on MRS, APT and MSE at $37^{\circ} \mathrm{C}$ in anaerobic conditions, coliform on VRBL at $37^{\circ} \mathrm{C}$ in aerobic condition and yeasts on MEA at $25^{\circ} \mathrm{C}$ in aerobic condition. Gram-positive, Gram-negative and yeasts isolates were identified by MALDI-TOF MS profiling. Totally, a number of 870 isolates were identified with score higher than 2. Hafnia alvei and Klebsiella oxytoca were the most frequently identified species of Gram-negative and Lactococcus lactis and Lactobacillus paracasei from Gram-positive bacteria. Dipodascus candidum and Yarrowia lipolitica were the most distributed yeasts. Lactic acid bacteria group was represented by Lactobacillus, Lactococcus and Pediococcus. The most abundant genera of lactic acid bacteria were Lactobacillus with 7 species. This study describs the indigenous microbiota of the traditional raw milk cheeses from Slovakia. Our results provide useful information on occurrence of valuable microbial strains for the industrialization of producing of the traditional cheese products.
\end{abstract}

Keywords: Gram-positive and Gram-negative bacteria, yeasts, „Bryndza“, MALDI-TOF MS Biotyper

\section{INTRODUCTION}

Raw milk was found to be contaminated with non-pathogenic and pathogenic microorganisms. Pathogens possibly present in raw milk may be originated from sick or apparently health animals or as a contamination from the environment or personnel during the collection or storage of milk. Contamination from animals can appears directly, eg. an endogenous infection then the milk is contaminated directly from the blood stream (systemic infection) or from udder in case of mastitis. Milk cross-contamination could be a result from contamination of faeces, the skin or the environment (Claeys et al., 2013). D'Amico and Donnelly (2010) did not find significant difference between the total microbial counts in raw milk from goats, sheep and cows. The total microbial counts goat and sheep milk were variable depending on milking, the number of milking sessions making up the milk mix, the type of milking system and herd size (Alexopoulos et al., 2011).

Consumer health has become a priority concern for food production. Sheep milk is expected to be an excellent source of nutrients (Balthazar et al., 2017). Sheep milk is rarely consumed as itself: mostly it is used for production of cheese and yogurt (Haenlein and Wendorff, 2006). Consequently, the milk quality has direct impact to the production of high-quality products and high cheese yield per liter of milk used in the cheese manufacture. Functional volume of milk used in the traditional manufacturing process depends on the type of cheese (Santillo and Albenzio, 2015).
The risks and benefits of traditional cheeses, which are frequently produced from raw milk, could be detected objectively by studying the microbiota of cheese inhabiting the product (Bhowmik and Marth, 1990). The microbial diversity and the benefits related to consumption of raw milk cheese depends on both the milk microbiota and traditional manufacturing practices, including a quality of inoculation practices. Traditional processing from farming to cheese making helps to maintain the diversity of microbiota of individual cheeses and the between lots of cheeses throughout processing (Litopoulou-Tzanetaki et al., 1989). More than 400 lactic acid bacteria species, Gram and catalase-positive bacteria, Gram-negative bacteria, yeasts and moulds have been detected in raw milk. The cheese surface is inhabited by numerous species of bacteria, yeasts and moulds, but the cheese cores reveals the smaller degree of biodiversity with a number of lactic acid bacteria species are numerically dominant (Montel $\boldsymbol{e t}$ al., 2014). Raw milk can contain pathogenic bacteria that have been raising public health concern and many of raw milk related outbreaks were describe since the beginning of dairy industry. The most common pathogenic bacteria found in raw milk and milk products were Salmonella, Listeria monocytogenes, Staphylococcus aureus and Escherichia coli (Markov et al., 2011).

Matrix-assisted laser desorption/ionization time of flight mass spectrometry (MALDI-TOF MS) is a tool in microbiological diagnostics which allow the identification of identification of microorganisms in various matrixes. Conventional identification methods rely on biochemical reactions and require additional pre-testing and incubation. In comparison, MALDI-TOF MS can 
directly identify bacteria and yeast from their colonies in very short period of time. This new and methodically simple approach reduces the cost of materials and duration of diagnostics (Wieser et al., 2012). Identification of microorganisms by MALDI-TOF MS is done by comparing the peptide mass fingerprint $(\mathrm{PMF})$ of tested organism with previously described PMFs from the database, or by matching the masses of biomarkers of tested microorganisms with the proteome database. In PMF matching, the MS spectrum of unknown microbial isolates is compared with the MS spectra of known microbial isolates in the database (Murray, 2012)

The aim of our study was to determine microbiota of traditional sheep cheese with mass spectrometry MALDI-TOF MS Biotyper.

\section{MATERIAL AND METHODS}

\section{Samples}

There were 30 samples of the Slovak national cheese „Bryndza“ examined in our study. Additionally, a total of 30 sheep milk cheese samples from the Slovak producers located in Slovakia were collected (Bukovina, Turčianské Teplice, Važec, Zvolenská Slatina). All samples were placed in sterile sample container and transported to laboratory on ice for microbiological investigations. Samples were kept in a refrigerator $\left(4 \pm 1^{\circ} \mathrm{C}\right)$ until the testing began. The primary dilution of the milk products was made for preparing the samples for testing: a $5 \mathrm{ml}$ of sample material was added to $45 \mathrm{ml}$ of $0.87 \%$ sterile saline. Then the serial dilutions $\left(10^{-2}\right.$ to $\left.10^{-4}\right)$ were done and a $100 \mu$ of each dilution was plated out.

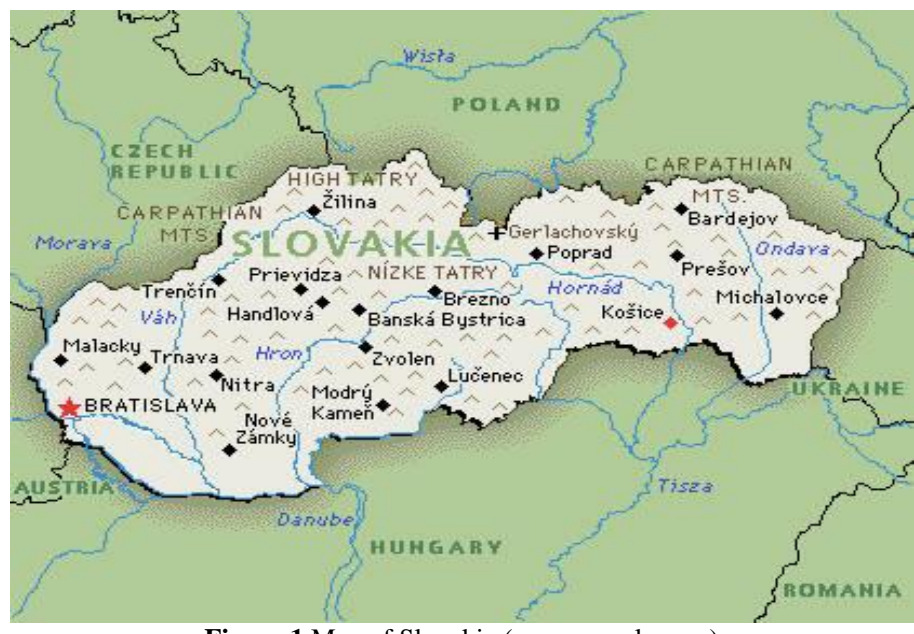

Figure 1 Map of Slovakia (www.google.com)

\section{Determination of total count of microorganisms}

Plate count agar (PCA, Sigma-Aldrich ${ }^{\circledR}$, St. Louis, USA) for total microbia count enumeration was used. Inoculated plates were incubated at $30^{\circ} \mathrm{C}$ for $24-48$ $\mathrm{h}$ and then examined for the characteristics of bacterial colonies.

\section{Isolation of coliform bacteria}

Violet red bile lactose agar (VRBGA, Sigma-Aldrich ${ }^{\circledR}$, St. Louis, USA) for enumeration of coliforms bacteria was used. Inoculated plates were incubated at $37^{\circ} \mathrm{C}$ for $24-48 \mathrm{~h}$ and then examined for the characteristics of typical colonies.

\section{Isolation of enterococci}

Enterococcus selective agar (ESA, Sigma-Aldrich ${ }^{\circledR}$, St. Louis, USA) for enumeration of enterococci was used. Inoculated plates were incubated at $37^{\circ} \mathrm{C}$ for 24-48 $\mathrm{h}$ and then examined for the characteristics of typical colonies.

\section{Isolation of Lactic Acid Bacteria (LAB)}

MRS (Main Rogose agar, Oxoid, UK), MSE (Mayeux, Sandine and Elliker in 1962, Oxoid, UK), and APT (All Purpose TWEEN ${ }^{\circledR}$ agar, Oxoid, UK) agars were used for enumeration of LAB including lactobacilli, leuconostocs and lactic acid streptococci as well as other microorganisms with high requirements for thiamine $\left(\right.$ Sigma-Aldrich $^{\circledR}$, St. Louis, USA). Inoculated agars were incubated at $30^{\circ} \mathrm{C}$ for $72 \mathrm{~h}$ anaerobically and then the bacterial growth was evaluated

\section{Isolation of yeasts}

Malt extract agar (Sigma-Aldrich ${ }^{\circledR}$, St. Louis, USA) and acid base indicator bromocresol green (Sigma-Aldrich ${ }^{\circledR}$, St. Louis, USA) $\left(0.020{\left.\mathrm{~g} . \mathrm{L}^{-1}\right)}^{\circ}\right.$ were used for yeasts identification. Inoculated plates were incubated at $25^{\circ} \mathrm{C}$ for 5 days aerobically and then the growth was evaluated.

\section{Sample preparation and MALDI-TOF MS measurement}

Prior to identification, the bacterial colonies were subcultured on TSA agar (Tryptone Soya Agar, Oxoid, UK) at $37^{\circ} \mathrm{C}$ for $18-24 \mathrm{~h}$. One colony of eight bacterial isolate was selected. Subsequently, the identification was performed using the Maldi TOF MS Biotyper as was described by Kačániová et al. (2019) Totally, a number of 870 isolates were identified with a score higher than 2 .

\section{RESULTS AND DISCUSSION}

Traditional bryndza is sharp, salty, greyish, grated and pin-rolled, crumbly, semispreadable $100 \%$ sheep cheese. There is no close equivalent in taste and texture among sheep, cow or goat cheeses. Unique food and drinks make up a significant part of Slovak culture, as the country produces several products which cannot be found or replicated in any other part of the world; bryndza cheese is one of those products (EC, 2008). The numbers of microorganisms in sheep cheese in our study is shown in table 1 . Total count of bacteria in bryndza ranged from 3.83 to $3.78 \mathrm{log}$ cfu.g ${ }^{-1}$. Enterococci were from 2.97 to $3.24 \log \mathrm{cfu}^{-1} \mathrm{~g}^{-1}$ in the studied samples. Coliform bacteria counts ranged from 3.07 to $3.85 \mathrm{log}$ cfu. $\mathrm{g}^{-1}$, lactic acid bacteria counts ranged from 3.05 to $3.13 \mathrm{log}$ cfu. $\mathrm{g}^{-1}$. The counts of yeasts ranged from 2.19 to $2.54 \log$ cfu. $\mathrm{g}^{-1}$

\begin{tabular}{cccccc}
\multicolumn{6}{c}{ Table 1 The number of isolated group of microorganisms from sheep cheese „Bryndza“ in cfu.g ${ }^{-1}$} \\
\hline Sample & Coliforms & Enterococcus & $\begin{array}{c}\text { Total Bacterial } \\
\text { Counts }\end{array}$ & $\begin{array}{c}\text { Lactic Acid } \\
\text { Bacteria }\end{array}$ & Yeasts \\
\hline 1. & $3.63 \pm 0.05$ & $3.05 \pm 0.03$ & $3.68 \pm 0.18$ & $3.05 \pm 0.04$ & $2.37 \pm 0.13$ \\
2. & $3.42 \pm 0.03$ & $2.97 \pm 0.02$ & $3.78 \pm 0.12$ & $3.07 \pm 0.07$ & $2.37 \pm 0.14$ \\
3. & $3.85 \pm 0.06$ & $3.01 \pm 0.02$ & $3.83 \pm 0.09$ & $3.09 \pm 0.07$ & $2.30 \pm 0.20$ \\
4. & $3.07 \pm 0.02$ & $3.08 \pm 0.06$ & $3.73 \pm 0.13$ & $3.13 \pm 0.02$ & $2.54 \pm 0.62$ \\
5. & $3.72 \pm 0.02$ & $3.04 \pm 0.07$ & $3.70 \pm 0.09$ & $3.11 \pm 0.05$ & $2.19 \pm 0.07$ \\
6. & $3.54 \pm 0.02$ & $3.07 \pm 0.04$ & $3.72 \pm 0.12$ & $3.10 \pm 0.04$ & $2.63 \pm 0.06$ \\
7. & $3.81 \pm 0.03$ & $3.13 \pm 0.02$ & $3.78 \pm 0.05$ & $3.11 \pm 0.02$ & $2.19 \pm 0.07$ \\
8. & $3.71 \pm 0.11$ & $3.24 \pm 0.22$ & $3.67 \pm 0.13$ & $3.09 \pm 0.03$ & $2.19 \pm 0.10$ \\
9. & $3.60 \pm 0.04$ & $3.13 \pm 0.02$ & $3.62 \pm 0.11$ & $3.11 \pm 0.01$ & $2.20 \pm 0.09$ \\
10. & $3.52 \pm 0.12$ & $3.11 \pm 0.05$ & $3.72 \pm 0.12$ & $3.13 \pm 0.02$ & $2.30 \pm 0.09$ \\
\hline
\end{tabular}

A total of 40 species of 10 microbial families and 20 genera (14 Gram-negative $\left(\mathrm{G}^{-}\right), 17 \mathrm{Gram}$-positive $\left(\mathrm{G}^{+}\right)$and 9 yeasts species) were identified in sheep cheese by MALDI-TOF Mass Spectrometry. The $\mathrm{G}^{-}, \mathrm{G}^{+}$and yeasts comprised $25.86 \%$ (225 isolates), $49.43 \%$ (430 isolates) and $24.71 \%$ (215 isolates), respectively. Isolated species of bacteria from cheese „Bryndza” are shown in table 2. 
Table 2 Isolated species of microorganisms from sheep cheese „Bryndza”

\begin{tabular}{|c|c|c|}
\hline Family & Genera & Species \\
\hline Moraxellaceae & Acinetobacter & Acinetobacter baumannii \\
\hline Moraxellaceae & Acinetobacter & Acinetobacter tandoii \\
\hline Bacillaceae & Bacillus & Bacillus pumilus \\
\hline Saccharomycetaceae & Candida & Candida catenulata \\
\hline Saccharomycetaceae & Candida & Candida krusei \\
\hline Saccharomycetaceae & Candida & Candida lusitaniae \\
\hline Saccharomycetaceae & Candida & Candida rugosa \\
\hline Saccharomycetaceae & Candida & Candida utilis \\
\hline Enterobacteriaceae & Citrobacter & Citrobacter braakii \\
\hline Enterobacteriaceae & Citrobacter & Citrobacter koseri \\
\hline Dipodascaceae & Dipodascus & Dipodascus candidum \\
\hline Dipodascaceae & Dipodascus & Dipodascus silvicola \\
\hline Enterobacteriaceae & Enterobacter & Enterobacter cloacae \\
\hline Enterobacteriaceae & Enterobacter & Enterobacter ludwigii \\
\hline Enterococcaceae & Enterococcus & Enterococcus faecalis \\
\hline Enterococcaceae & Enterococcus & Enterococcus faecium \\
\hline Enterococcaceae & Enterococcus & Enterococcus hirae \\
\hline Enterobacteriaceae & Escherichia & Escherichia coli \\
\hline Enterobacteriaceae & Hafnia & Hafnia alvei \\
\hline Enterobacteriaceae & Klebsiella & Klebsiella oxytoca \\
\hline Enterobacteriaceae & Klebsiella & $\begin{array}{l}\text { Klebsiella pneumoniae ssp. } \\
\text { ozaenae }\end{array}$ \\
\hline Enterobacteriaceae & Klebsiella & $\begin{array}{c}\text { Klebsiella pneumoniae ssp. } \\
\text { pneumoniae }\end{array}$ \\
\hline Lactobacillaceae & Lactobacillus & Lactobacillus brevis \\
\hline Lactobacillaceae & Lactobacillus & Lactobacillus harbinensis \\
\hline Lactobacillaceae & Lactobacillus & Lactobacillus johnsonii \\
\hline Lactobacillaceae & Lactobacillus & Lactobacillus plantarum \\
\hline Lactobacillaceae & Lactobacillus & $\begin{array}{l}\text { Lactobacillus paracasei ssp. } \\
\text { paracasei }\end{array}$ \\
\hline Lactobacillaceae & Lactobacillus & Lactobacillus paraplantarum \\
\hline Lactobacillaceae & Lactobacillus & Lactobacillus suebicus \\
\hline Streptococcaceae & Lactococcus & Lactococcus lactis ssp lactis \\
\hline Streptococcaceae & Lactococcus & Lactococcus lactis \\
\hline Microbacteriaceae & Microbacterium & Microbacterium liquefaciens \\
\hline Lactobacillaceae & Pediococcus & Pediococcus acidilactici \\
\hline Saccharomycetaceae & Pichia & Pichia cactophila \\
\hline Enterobacteriaceae & Raoultella & Raoultella ornithinolytica \\
\hline Enterobacteriaceae & Serratia & Serratia liquefaciens \\
\hline Staphylococcaceae & Staphylococcus & $\begin{array}{c}\text { Staphylococcus aureus ssp. } \\
\text { aureus }\end{array}$ \\
\hline Staphylococcaceae & Staphylococcus & Staphylococcus pasteuri \\
\hline Xanthomonadaceae & Stenotrophomonas & $\begin{array}{l}\text { Stenotrophomonas } \\
\text { maltophilia }\end{array}$ \\
\hline Dipodascaceae & Yarrowia & Yarrowia lipolytica \\
\hline
\end{tabular}

Altogether, 14 species of Gram-negative bacteria were isolated. Klebsiella spp. were represented by three species and were the most widespread bacterial genus. The most distributed bacterial species were Hafnia alvei, Klebsiella oxytoca and Enterobacter cloacae (table 3).

Altogether, 17 bacterial species of Gram-positive bacteria were isolated from sheep cheese. Lactobacillus spp. were the most widespread genus represented with 7 species. Lactococcus lactis was the most frequently isolated bacterial species (table 4).

Previous culture-independent studies showed the diversity of bacteria and fungi and the changes is their population during the production of bryndza (Chebeňová-Turcovská et al., 2011; Pangallo et al., 2014). Interactions between the lactic acid bacteria and Galactomyces/Geotrichum group and coagulase-positive staphylococci were studied as well (Hudecová et al., 2011, Medved'ová and Valík, 2012). The culture-depended methods showed that the bryndza samples contained lactococci, lactobacilli and Galactomyces/Geotrichum in high numbers. Majority of lactobacilli were identified as Lactobacillus paracasei and Lb. plantarum and lactococci as Lactococcus lactis with PCRbased identification methods. Culture-independent analysis revealed that Lactococcus spp. followed by Streptococcus spp. and Leuconostoc spp were the most abundant bacterial genera (Šaková et al., 2015).
Altogether, nine yeast species were isolated from sheep cheese. Candida spp. were the most abundant yeast genus, while Dipodascus candidum was the most frequently isolated yeast species (table 5).

Table 3 Isolated species of Gram-negative bacteria from sheep cheese „Bryndza”

\begin{tabular}{lcc}
\hline Microorganism & No. of isolates & $\begin{array}{c}\text { No. of isolates } \\
\text { in \% }\end{array}$ \\
\hline Acinetobacter baumannii & 15 & 6.7 \\
Acinetobacter tandoii & 6 & 2.7 \\
Citrobacter braakii & 8 & 3.6 \\
Citrobacter koseri & 7 & 3.1 \\
Enterobacter cloacae & 21 & 9.3 \\
Enterobacter ludwigii & 15 & 6.7 \\
Escherichia coli & 15 & 6.7 \\
Hafnia alvei & 45 & 20.0 \\
Klebsiella oxytoca & 25 & 11.1 \\
Klebsiella pneumoniae ssp. ozaenae & 10 & 4.4 \\
Klebsiella pneumoniae ssp. & 15 & 6.7 \\
pneumoniae & 20 & 8.9 \\
Raoultella ornithinolytica & 15 & 6.7 \\
Serratia liquefaciens & 8 & 3.6 \\
Stenotrophomonas maltophilia & & \\
\hline
\end{tabular}

Table 4 Isolated species of Gram positive microorganisms from sheep cheese „Bryndza”

\begin{tabular}{lcc}
\hline Microorganism & No. of isolates & $\begin{array}{c}\text { No. of isolates } \\
\text { in \% }\end{array}$ \\
\hline Bacillus pumilus & 22 & 5.1 \\
Enterococcus faecalis & 25 & 5.8 \\
Enterococcus faecium & 20 & 4.7 \\
Enterococcus hirae & 15 & 3.5 \\
Lactobacillus brevis & 34 & 7.9 \\
Lactobacillus harbinensis & 35 & 8.1 \\
Lactobacillus johnsonii & 30 & 7.0 \\
Lactobacillus plantarum & 25 & 5.8 \\
Lactobacillus paracasei ssp. & 15 & 3.5 \\
paracasei & 35 & 8.1 \\
Lactobacillus paraplantarum & 15 & 3.5 \\
Lactobacillus suebicus & 50 & 11.6 \\
Lactococcus lactis ssp. lactis & 55 & 12.8 \\
Lactococcus lactis & 9 & 2.1 \\
Microbacterium liquefaciens & 20 & 4.7 \\
Pediococcus acidilactici & 10 & 2.3 \\
Staphylococcus aureus ssp. aureus & 15 & 3.5 \\
Staphylococcus pasteuri & & \\
\hline
\end{tabular}

Table 5 Isolated yeasts from sheep cheese „Bryndza”

\begin{tabular}{lcc}
\hline Yeast species & No. of isolates & $\begin{array}{c}\text { No. of isolates } \\
\text { in \% }\end{array}$ \\
\hline Candida catenulata & 15 & 6.98 \\
Candida krusei & 25 & 11.63 \\
Candida lusitaniae & 25 & 11.63 \\
Candida rugosa & 15 & 6.98 \\
Candida utilis & 10 & 4.65 \\
Dipodascus candidum & 50 & 23.26 \\
Dipodascus silvicola & 25 & 11.63 \\
Pichia cactophila & 5 & 2.32 \\
Yarrowia lipolytica & 45 & 20.93 \\
\hline
\end{tabular}

Galactomyces/Geotrichum, and yeasts Yarrowia lipolytica, Kluyveromyces lactis and Debaryomyces hansenii were the main representative of eukaryotic microbiota in study of Šaková et al., 2015. Yarrowia lipolytica was identified as one of the most abundant species in the present study.

Composition and activity of microflora is believed to have a great impact on the flavour of bryndza cheese. The compounds contained in ewes' milk and from the products of fermentation of the substrate by microflora were responsible for typical sensory characteristics (Sádecká et al., 2014). In previous studies, Lactobacillus spp. (Berta et al., 1990), Lactococcus spp., Streptococcus spp., Enterococcus spp., Kluyveromyces marxianus and Galactomyces geotrichum were identified as the main microorganism of bryndza cheese (Görner, 1980; 
Palo and Kaláb, 1984; Görner and Valík, 2004). Enterococci (Jurkovič et al., 2006b), staphylococci (Mikulášová et al., 2014) and fungal species (Laurenčík et al., 2008) were identified in bryndza cheese as well.

Lactobacillus spp., Lactococcus spp., Streptococcus spp., Enterococcus spp., Kluyveromyces marxianus and Geotrichum candidum are believed to influence the characteristic organoleptic properties of the Slovakian bryndza cheese (Valík, 2004; EC, 2007). There are only limited studies on microbiota of Slovakian bryndza cheese with mostly classical microbiological methods were applied. Modern methods have been used for characterization of enterococci, potentia probiotic cultures or producers of bacteriocins, and pathogenic coliforms responsible for safety problems (Lauková and Czikková, 2001; Lauková et al., 2003; Jurkovič et al., 2006a; Jurkovič et al., 2006b).

Lactobacillus species identified in bryndza cheese in this study, i. e. Lb. brevis, are well known microorganism in cheeses and may contribute to flavour development by peptidolytic activities and aminoacid catabolism (Olson, 1990;

Poveda et al., 2002; Wouters et al., 2002; Kieronczyk et al., 2003).

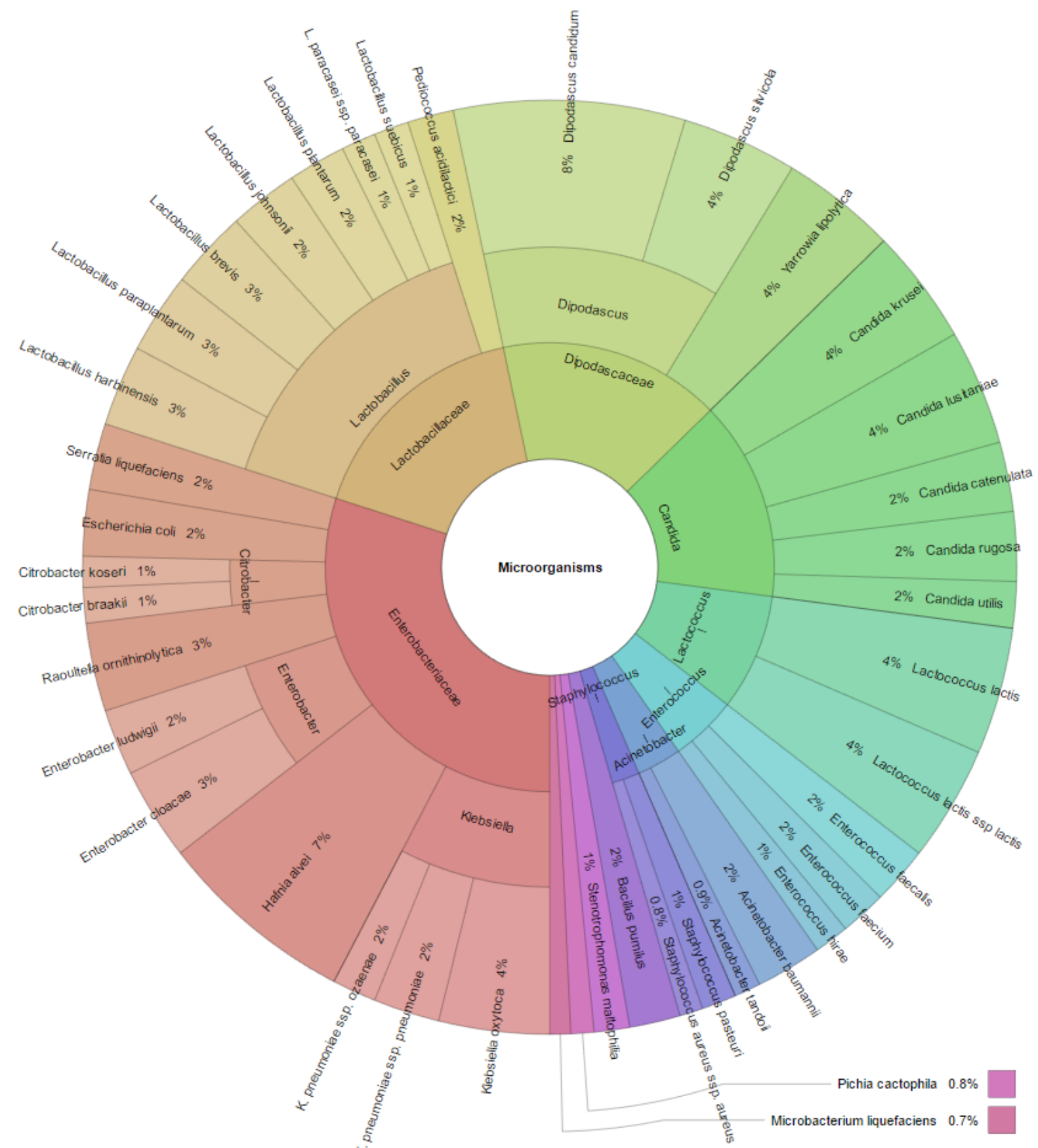

Figure 2 Microbiota of sheep cheese "Bryndza" of Slovak origin

\section{CONCLUSION}

Microbiologically, the 40 species of 20 bacterial genera of three main groups of microorganisms were identified with MALDI-TOF Mass Spectrometry. The Gram-negative, Gram-positive bacteria and yeasts comprised 25.86\% (225 isolates) $49.43 \%$ (430 isolates) and $24.71 \%$ (215 isolates), accordingly. Fas microbial identification is in high demand in industry for improving of HACCP based procedures, reduce biocide consumption and to avoid the distribution of contaminated products. The speed and precision of microbial identification with MALDI-TOF-MS were well described for clinical isolates, but the present study show that the methods could be applicable for dairy producing and industrial applications.
Acknowledgments: Work was supported by the grants APVV-16-0244 "Qualitative factors affecting the production and consumption of milk and cheese".

\section{REFERENCES}

Alexopoulos, A., Tzatzimakis, G., Bezirtzoglou, E., Plessas, S., Stavropoulou, E., Sinapsis, E. \& Abas, Z. (2011). Microbiological quality and related factors of sheepmilk produced in farms of NE Greece. Anaerobe, 17(6), 276-279. https://doi.org/10.1016/j.anaerobe.2011.03.011

Balthazar, C.F., Pimentel, T.C., Ferrão, L.L., Almada, C.N., Santillo, A., Albenzio, M., Mollakhalili, N., Mortazavian, A.M., Nascimento, J.S., Silva, M.C., Freitas, M.Q., Sant'ana, A.S., Granato, D. \& Cruz, A.G. (2017). Sheep 
milk: physicochemical characteristics and relevance for functional food development. Comprehensive Reviews in Food Science and Food Safety, 16(2), 247-262. https://doi.org/10.1111/1541-4337.12250

Berta, G., Chebeňová, V., Brežná, B., Pangallo, D., Valík, L. \& Kuchta, T. (1990). Identification of lactic acid bacteria in Slovakian bryndza cheese. Journal of Food and Nutrition Research, 48, 65-71.

Bhowmik, T., Marth, E. H. (1990). Role of Micrococcus and Pediococcus species in cheese ripening. Journal of Dairy Science, 73(4), 859-866. https://doi.org/10.3168/jds.s0022-0302(90)78740-1

Claeys, W. L., Cardoen, S., Daube, G., De Block, J., Dewettinck, K., Dierick, K. De Zutter, L., Huyghebaert, A., Imberechts, H., Thiange, P., Vandenplas, Y. \& Herman, L. (2013). Raw or heated cow milk consumption: review of risks and benefits. Food Control, 31(1), 251-262. https://doi.org/10.1016/j.foodcont.2012.09.035

Commission Regulation (EC) No 676/2008 (2008). registering certain names in the Register of protected designations of origin and protected geographical indications (Ail de la Drôme (PGI), Všestarská cibule (PDO), Slovenská bryndza (PGI), Ajo Morado de Las Pedroñeras (PGI), Gamoneu or Gamonedo (PDO), Alheira de Vinhais (PGI), Presunto de Vinhais or Presunto Bísaro de Vinhais (PGI)). Official Journal of the European Union, L 189, 19-20.

D'Amico, D.J. \& Donnelly, C.W. (2010). Microbiological quality of raw milk used forsmall-scale artisan cheese production in Vermont: effect of farm characteristics and practices. Journal of Dairy Science, 93(1), 134-147. https://doi.org/10.3168/jds.2009-2426

Görner, F. (1980). Der Brinsekäse aus Schafmilch (Brimsen). Nahrung, 4, 157 162

Görner, F. \& Valík, L. (2004). Aplikovaná mikrobiológia požívatín. (Applied Food Microbiology.) 1st ed. Bratislava : Malé centrum, 2004. 528 pp. ISBN 80967064-9-7.

Haenlein, G.F.W. \& Wendorff, W.L. (2006). Sheep milk - production and utilization of sheep milk. Handbook of milk of non-bovine mammals. Oxford and Ames, Iowa: Blackwell Publishing, Lts, 457 p. ISBN 9780813820514 https://doi.org/10.1002/9780470999738.ch1

Hudecová, A., Valík, L., Liptáková, D., Pelikánová, J. \& Čižniar, M. (2011) Effect of temperature and lactic acid bacteria on the surface growth of Geotrichum candidum. Czech Journal of Food Sciences, 29, S61-S68. https://doi.org/10.17221/265/2011-cjfs

Chebeňová-Turcovská, V., Ženišová, K., Kuchta, T., Pangallo, D. \& Brežná, B. (2011). Culture independent detection of microorganisms in traditional Slovakian bryndza cheese. International Journal of Food Microbiology, 150(1), 73-78. https://doi.org/10.1016/j.ijfoodmicro.2011.07.020

Jurkovič, D., Križková, L., Dušinský, R., Belicová, A., Sojka, M., Krajčovič, J. \& Ebringer, L. (2006a). Identification and characterization of enterococci from bryndza cheese. Letters in Applied Microbiology, 42, 553-559. https://doi.org/10.1111/j.1472-765x.2006.01918.x

Jurkovič, D., Križková, L., Sojka, M., Belicová, A., Dušinský, R., Krajčovič, J., Snauwaert, C., Naser, S. Vandamme, P. \& Vancanneyt, M. (2006b). Molecular identification and diversity of enterococci isolated from Slovak Bryndza cheese Journal of General and Applied Microbiology, 52(6), 329-337. https://doi.org/10.2323/jgam.52.329

Kačániová, M., Klūga, A., Kántor, A., Medo, J., Žiarovská, J., Puchalski, C. \& Terentjeva, M. (2019). Comparison of MALDI-TOF MS Biotyper and 16S rDNA sequencing for the identification of Pseudomonas species isolated from fish. Microbial Pathogenesis, 132, 313-318 https://doi.org/10.1016/j.micpath.2019.04.024

Kieronczyk, A., Skeie, S., Langsrud, T. \& Yvon, M. (2003). Cooperation between Lactococcus lactis and nonstarter lactobacilli in the formation of cheese aroma from amino acids. Applied and Environmental Microbiology, 69(2), 734 739. https://doi.org/10.1128/aem.69.2.734-739.2003

Lauková, A. \& Czikková, S. (2001). Antagonistic effect of enterocin CCM 4231 from Enterococcus faecium on "bryndza", a traditional Slovak dairy product from sheep milk. Microbiological Research, 156(1), 31-34. https://doi.org/10.1078/0944-5013-00078

Lauková, A., Kuzmová, R., Marcináková, M. \& Strompfová, V. (2003). Stability and effect of probiotics in a full-fat winter bryndza. Slovenský veterinársky časopis, 28(5), 40-41.

Laurenčík, M., Sulo, P., Sláviková, E., Piecková, E., Seman, M. \& Ebringer, L. (2008). The diversity of eukaryotic microbiota in the traditional Slovak sheep cheese - Bryndza. International Journal of Food Microbiology, 127(1-2), 176179. https://doi.org/10.1016/j.ijfoodmicro.2008.06.016

Litopoulou-Tzanetaki, E., Graham, D.C. \& Beyatli, Y. (1989). Detection of pediococci and other nonstarter organisms in American Cheddar cheese. Journal of Dairy Science, 72(4), 854-858. https://doi.org/10.3168/jds.s00220302(89)79177-3

Markov, K., Perši, N., Pleadin, J., Čvek, D., Radošević, V. \& Delaš, F. (2011). Characterization of natural microflora and chemical parameters in fresh domestic cheese. Veterinarska stanica, 42, 211-218.

Medved'ová, A. \& Valík, L. 2012. Staphylococcus aureus: Characterisation and quantitative growth description in milk and artisanal raw milk cheese production.
In: Eissa, A. A.: Structure and function of food engineering. Rijeka : InTech, 71 102. ISBN 978-953-51-0695-1.

Mikulášová, M., Valáriková, J., Dušinský, R., Chovanová, R. \& Belicová, A. (2014). Multiresistance of Staphylococcus xylosus and Staphylococcus equorum from Slovak Bryndza cheese. Folia Microbiologica, 59(3), 223-227. https://doi.org/10.1007/s12223-013-0286-y

Montel, M. C., Buchin, S., Mallet, A., Delbes-Paus, C., Vuitton, D. A. Desmasures, N. \& Berthier, F. (2014). Traditional cheeses: Rich and diverse microbiota with associated benefits. International Journal of Food Microbiology, 177, 136-154. https://doi.org/10.1016/i.ijfoodmicro.2014.02.019

Murray, P.R. (2012). What is new in clinical microbiology-microbia identification by MALDI-TOF mass spectrometry. The Journal of Molecular Diagnostics, 14(5), 419-423. https://doi.org/10.1016/j.jmoldx.2012.03.007

Olson, N.F. (1990). The impact of lactic acid bacteria on cheese flavor. FEMS Microbiology Letters, 87(1-2), 131-147. https://doi.org/10.1016/0378 1097(90)90702-r

Palo, V. \& Kaláb, M. (1984). Slovak sheep cheeses. Milchwissenschaft, 39, 518 521

Pangallo, D., Šaková, N., Koreňová, J., Puškárová, A., Kraková, L., Valík, L. \& Kuchta, T. (2014). Microbial diversity and dynamics during the production of May bryndza cheese. International Journal of Food Microbiology, 170, 38-43 https://doi.org/10.1016/j.ijfoodmicro.2013.10.015

Poveda, J.M., Sousa, M.J., Cabezas, L. \& Mcsweeney, P.L.H. (2002) Preliminary observations on proteolysis in Manchego cheese made with definedstrain starter culture and adjunct starter (Lactobacillus plantarum) or commercial starter. International Dairy Journal, 14, 169-178 https://doi.org/10.1016/s0958-6946(02)00150-4

Publication of an application pursuant to Article 6(2) of Council Regulation (EC) No 510/2006 (2007) on the protection of geographical indications and designations of origin for agricultural products and foodstuffs. Official Journal of the European Union, C 232, 17-22.

Sádecká, J., Kolek, E., Pangallo, D., Valík, L. \& Kuchta, T. (2014). Principal volatile odorants and dynamics of their formation during the production of May Bryndza cheese. Food Chemistry, 150, 301-306. https://doi.org/10.1016/j.foodchem.2013.10.163

Santillo, A. \& Albenzio, M. (2015). Sensory profile and consumers' liking of functional ovine cheese. Foods, 4(4), 665-677. https://doi.org/10.3390/foods4040665

Šaková, N., Sádecká, J., Lejková, J., Puškárová, A., Koreňová, J., Kolek, E. Valík, L., Kuchta, T. \& Pangallo, D. (2015). Characterization of May bryndza cheese from various regions in Slovakia based on microbiological, molecular and principal volatile odorants examination. Journal of Food and Nutrition Research, 54(3), 239-251

Valík, L': Mikrobiológia syrov. In: Görner, F., Valík, L. Aplikovaná mikrobiológia požívatín. Bratislava : Malé Centrum, 2004, pp. 273-338.

Wieser, A., Schneider, L., Jung, J. \& Schubert, S. (2012). MALDI-TOF MS in microbiological diagnostics - identification of microorganisms and beyond ( $\mathrm{mini}$ review). Applied Microbiology and Biotechnology, 93(3), 965-974. https://doi.org/10.1007/s00253-011-3783-4

Wouters, T.M., Ayad, E.H.E., Hugenholtz, J. \& Smith, G. (2002). Microbes from raw milk for fermented dairy products. International Dairy Journal, 12(2-3), 91 109. https://doi.org/10.1016/s0958-6946(01)00151-0 